\title{
Tough road to LHC is worth taking
}

There are problems in getting collaboration on the LHC off the ground, but it should be possible to overcome them, to the benefit of all concerned.

THE design and construction of the proposed Large Hadron Collider (LHC) at the European Laboratory for Particle Physics (CERN) in Geneva, Switzerland, will be a tough technical challenge. But the history of particle physics provides strong grounds for believing the challenge can be met.

The same cannot quite be said of the challenge faced by those now working to secure US backing for the LHC project. The US Congress has never before been asked to provide the kind of funding required for LHC - perhaps $\$ 500$ million over 8-10 years to help build a scientific facility abroad. There are, however, grounds for believing that US backing will eventually be secured.

The existing CERN partners are firmly locked into their collaboration by international treaty. But Congress alone will decide what the United States will contribute, and it will do so each year and every year. It will not be bound by its own previous declarations, still less by the views of US government officials.

High-energy physicists are justifiably encouraged that negotiations between CERN and the US Department of Energy (DOE) have reached the stage at which both sides can publicly agree on the amount of US support they are discussing (see Nature 380, 369; 1996). But it is hardly time to uncork the champagne.

The United States had been hinting for some time at a \$400million contribution. The Europeans had hoped for up to twice as much: they reasoned that American scientists would use the machine more than any other national group. The real cost of the project, including the contribution of European physicists whose work will not be billed to it, is considerably higher than the officially stated project cost of $\$ 3$ billion.

After meetings in Washington this past winter, at which US budget problems loomed large, the United States suggested a figure as a basis for negotiation - $\$ 450$ million, plus or minus $\$ 50$ million, from the DOE and an additional $\$ 80$ million from the National Science Foundation. Christopher Llewellyn Smith, the director of CERN, took this back to a CERN council meeting, whose members swallowed hard, looked reality in the face, and reluctantly agreed that the figure could form a basis for negotiation.

The two sides have given themselves until the end of the year to come up with a deal. That process in itself could be endangered by the US presidential elections in November: Martha Krebs, assistant energy secretary and head of the US negotiating team, is out of a job if President Bill Clinton loses. But if things go smoothly, an agreement could be accepted by the CERN Council and put to Congress at the beginning of next year. An effort will then be made to pass an authorization bill - an approval, in principle, of future expenditure - to show that Congress supports the project. Such an endorsement would still leave Congress appropriations committees to decide, each year, whether LHC support should continue inside a budget that will no doubt grow even tighter and more difficult every time.

The influential High Energy Physics Advisory Panel (HEPAP) said, in 1994, that the United States could afford the contribution in the peak period of 1999-2004 because two major high-energy physics construction projects in the United States will be completed by 1998 . But the high-energy physics budget of $\$ 650$ million is normally lumped in with a nuclear physics budget of $\$ 350$ million, and the latter needs to grow sharply to enable the full opera- tion of two other facilities that will be completed shortly. And the combined budget of $\$ 1$ billion could be severely curtailed by budget pressure at DOE; one set of figures has it collapsing to $\$ 760$ million by 1999.

Still, where would we be without hope? US physicists need the LHC to keep up with the Europeans and the project will benefit greatly from US technical expertise. HEPAP retains considerable prestige, and leaders of both parties in Congress will pay attention to its advice. James Sensenbrenner (Republican, Wisconsin), who is likely to be the next chair of the Science Committee in the House of Representatives, is a strong internationalist, as are most of the congressional leaders who oversee this programme on both sides of the aisle, in both House and Senate.

That could change, of course. A number of these leaders will retire this year. It will be an immense challenge for the particle physics community to ensure that their successors understand and support what is being planned at CERN. They must also understand what is at stake, which is the credibility of the United States as a reliable partner in a field of science where future progress will depend on international collaboration.

\section{Private capital is no answer}

The British government should admit that its proposed solution for equipment funding in universities is mistaken.

ONE sign of strong government is the willingness to admit mistakes and the British government has an opportunity to salvage a small part of its increasingly fragile reputation. At issue is the deteriorating state of the scientific facilities used for teaching and research in British universities. The mistake is the belief that universities should be able to find private capital to fund such facilities.

The fallacy has already made a serious dent in the government's reputation as a supporter of science. In the 1995-96 budget figures, released in February, officials pointed out proudly that spending on science through the research councils will be roughly in line with the anticipated rate of inflation. But this welcome gain has been almost wiped out by a decision to impose a significant cut on capital spending for equipment by universities.

If these cuts are sustained, academic morale will inevitably drop even further. As a report published this week points out (see page 572), overcrowding and under-investment are already threatening the ability of universities to meet their research responsibilities. Private capital is not the solution to research equipment needs. Universities cannot borrow such money, being unable to provide a guarantee of a sufficient income stream to meet repayments. Industry - like the research charities - says it is the government's role to see that university infrastructure is adequately financed.

Finding a solution will not be easy. But the amount of money involved could probably be met by careful surgery elsewhere, while the needs it would meet are essential for the health of British science. Government ministers seem to have begun to recognize the dangers of the course they are on. The next step will be to turn this into remedial action. 